\title{
Some interesting records of corticioid and poroid fungi from district Kullu (Himachal Pradesh)
}

\author{
Ellu Ram, Ramandeep Kaur, Avneet Pal Singh* and Gurpaul Singh Dhingra \\ Department of Botany, Punjabi University, Patiala, 147002, Punjab, India \\ *Corresponding author Email: avneetbot@gmail.com
}

(Submitted on September 28, 2019; Accepted on November 19, 2019)

\section{ABSTRACT}

An account of three corticioid fungi i.e., Byssomerulius corium (Pers.) Parmasto, Crustoderma drynium (Berk. \& M.A. Curtis) Parmasto, Skvortzovia georgica (Parmasto) G. Gruhn \& Hallenb. and four poroid species i.e., Earliella scabrosa (Pers.) Gilb. \& Ryvarden, Ganoderma australe (Fr.) Pat., Physisporinus lineatus (Pers.) F. Wu, Jia J. Chen \& Y.C. Dai and Pycnoporus sanguineus (L.) Murrill, is presented based on the collections made from district Kullu (Himachal Pradesh). All these seven species are new additions to the mycoflora of district Kullu (Himachal Pradesh). Of these, Skvortzovia georgica and Pycnoporus sanguineus are being described as new record for India and Himachal Pradesh, respectively. It is also important to mention here that five of the genera namely, Byssomerulius, Crustoderma, Earliella, Pycnoporus and Skvortzovia are being described for the first time from the study area.

KEYWORDS: Corticioids, polypores, wood rotting fungi, resupinate, basidiocarp.

\section{INTRODUCTION}

The corticioid and poroid fungi (Agaricomycetes, Basidiomycota) are characteristic in having annual to perennial, resupinate to effused-reflexed to pileate, sessile to stipitate basidiocarps. The hymenium is exposed, organised either in the form of a sheet on the susbstrate (corticioid fungi) or is lining the tubes (poroid fungi) that open through pore. These fungi are mainly responsible for wood decay and few of them are forest pathogens. Some of these fungi are also used in the traditional medicinal system. Earlier workers (Rattan, 1977; Singh, 2007; Dhingra et al., 2014; Priyanka, 2012; Kaur, 2012; Sharma, 2012; Kaur, 2013 and Prasher and Ashok, 2013) described 271 taxa of these fungi from district Kullu in Himachal Pradesh. During the fungal forays conducted in different localities of district Kullu in Himachal Pradesh in the rainy season of the years 2014-2016, some interesting specimens of corticioid and poroid fungi were collected. The morphotaxonomic details of these fungi when compared with the literature, (Bakshi, 1971; Rattan, 1977; Bernicchia and Gorjon, 2010; Sharma, 2000, 2012; Ryvarden and Melo, 2014; Kaur, 2017; Kaur et al., 2017a,b, 2018; Brar et al., 2018; Mycobank, 2019) resulted in the identification of three corticioid i.e. Byssomerulius corium (Pers.) Parmasto, Crustoderma drynium (Berk. and M.A. Curtis) Parmasto, Skvortzovia georgica (Parmasto) G. Gruhn \& Hallenb. and four poroid species i.e. Earliella scabrosa (Pers.) Gilb. \& Ryvarden, Ganoderma australe (Fr.) Pat., Physisporinus leneatus (Pers.) F. Wu, Jia J. Chen \& Y.C. Dai and Pycnoporus sanguineus (L.) Murrill. All the seven species are new additions to the mycoflora of district Kullu (Himachal Pradesh). It is pertinent to mention here that Skvortzovia georgica is being described for the first time from India and Pycnoporus sanguineus is a new record for Himachal Pradesh. Five genera i.e. Byssomerulius, Crustoderma, Earliella, Pycnoporus and Skvortzovia are new generic records for the study area. The colour standards followed are as per Kornerup and Wanscher (1978).

\section{TAXONOMIC DESCRIPTIONS}

1. Byssomerulius corium (Pers.) Parmasto, Eesti NSV Teaduste Akadeemia Toimetisd 16: 383, 1967.

Thelephora corium Pers., Synopsis methodica fungorum: 574, 1801.

Figs. 1-4

Basidiocarp resupinate, effused, adnate, $\leq 250 \mu \mathrm{m}$ thick in section; hymenial surface merulioid, orange white to pale orange when fresh, grayish orange on drying; margin thinning, become reflexed with age, paler concolorous to indeterminate. Hyphal system monomitic. Generative

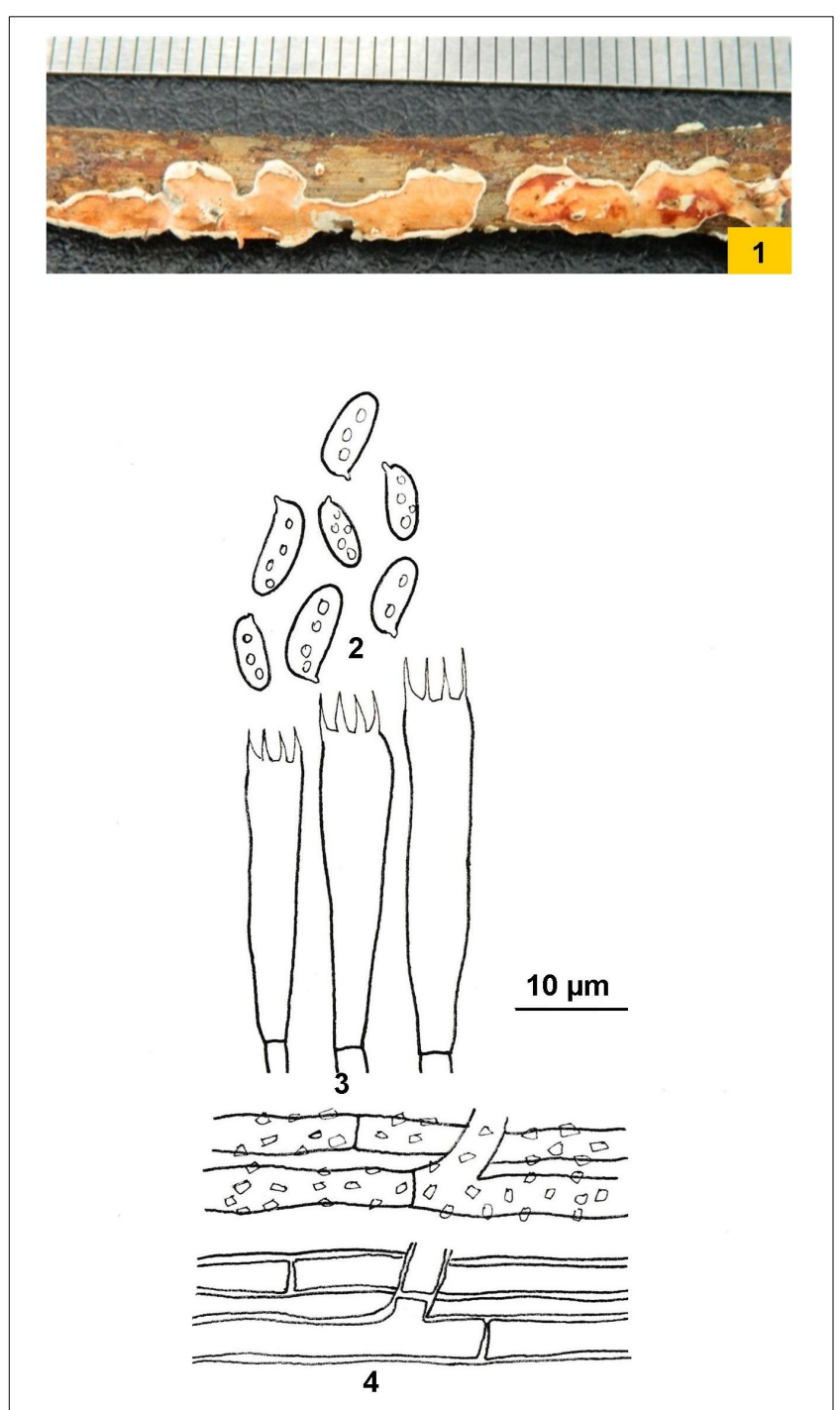

Figs. 1-4 Byssomerulius corium: 1. Basidiocarp showing hymenial surface; 2. Basidiospores; 3. Basidia; 4. Generative hyphae. 
hyphae branched, septate, without clamps, incrusted with needle like crystals; basal hyphae up to $5 \mu \mathrm{m}$ wide, thickwalled, loosely interwoven; subhymenial hyphae up to 3.2 $\mu \mathrm{m}$ wide, thin- to somewhat thick-walled, compact, vertical. Cystidia none. Basidia 27-34 × 5.6-6.8 $\mu \mathrm{m}$, narrowly clavate, without basal clamp, 4-sterigmate; sterigmata up to $4.8 \mu \mathrm{m}$ long. Basidiospores 5-7 $\times 2.4-3 \mu \mathrm{m}$, ellipsoid, thinwalled, smooth, acyanophilous, inamyloid.

Collection examined: Himachal Pradesh: Kullu, Banjar, Manglore, on sticks of Rubus ellipticus, Ellu 9559 (PUN), 6. 08.2014.

Remarks: Bakshi (1971) described this species for the first time from India as Merulius corium from Dehradun (Uttarakhand). Later, Dhingra et al., (2011) listed it as Byssomerulius corium from Eastern Himalaya. Sharma (2012) and Sanyal (2014) described it from Uttrakhand. Ranadive (2013) also listed it but without mentioning the specific localities, in his check list. Recently, Kaur et al., (2018) described it from district Shimla in Himachal Pradesh.

2. Crustoderma dryinum (Berk. \& M.A. Curtis) Parmasto, Consp. System. Corticiac. (Tartu): 88, 1968.

Corticium dryinum Berk. and M.A. Curtis, Grevillea 1(12): 179,1873

Figs. 5-9

Basidiocarp resupinate, effused, adnate, $\leq 300 \mu \mathrm{m}$ thick in section; hymenial surface smooth to tuberculate, orange white to pale orange to light grayish orange when fresh, somewhat darkening on drying; margin thinning, paler to concolorous. Hyphal system monomitic. Generative hyphae up to $6 \mu \mathrm{m}$ wide, branched, septate, clamped; basal hyphae thick-walled; subhymenial hyphae thin- to thick-walled. Cystidia 94-112 × 9-10 $\mu \mathrm{m}$, subcylindrical, thick-walled, with basal clamp; projecting up to $58 \mu \mathrm{m}$ out of the hymenium. Basidia 20.5-32.5 $\times 5.5-7 \mu \mathrm{m}$, clavate, with basal clamp, 4-sterigmate; sterigmata up to $5 \mu \mathrm{m}$ long. Basidiospores 6.8-10 × 3-4.3 $\mu \mathrm{m}$, ellipsoid to subcylindrical, thin-walled, smooth, inamyloid, acyanophilous.

Collection examined: Himachal Pradesh: Kullu, Banjar, Manglore, Tippra, on decaying stump of Cedrus deodara, Ellu 9560 (PUN), 25.09.2015.

Remarks: Crustoderma drynum was reported for the first time from Eastern Himalaya by Thind and Dhingra (1985). Besides Eastern Himalaya, it is also known from district Shimla, Chamba and Solan in Himachal Pradesh based upon the reports by Singh (2007), Priyanka (2012) and Dhingra et al. (2014).

3. Earliella scabrosa (Pers.) Gilb. \& Ryvarden, Mycotaxon 22(2): 364, 1985.

Polyporus scabrosus Pers., Botanique (Nagpur) 5: 172, 1827.

Figs. 10-17

Basidiocarp annual, effused-reflexed to pileate, solitary to imbricate; pilei up to $4 \times 3 \times 0.8 \mathrm{~cm}$, applanate, coriaceous to tough when fresh, hard and woody on drying; abhymenial surface smooth to tomentose, radially sulcate, azonate to zonate, yellowish white to greyish orange and covered with a thin, reddish brown to dark brown cuticle which starts from

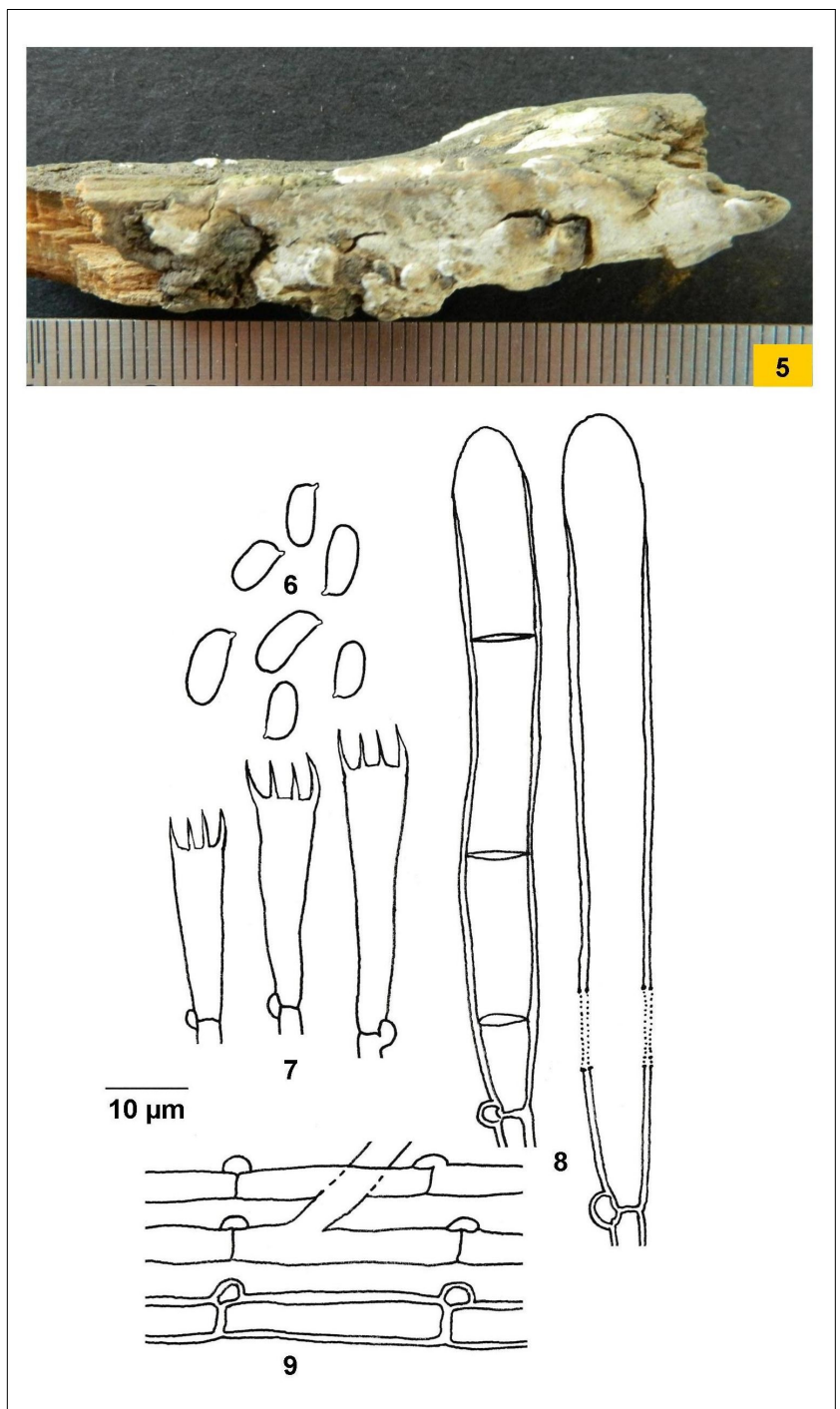

Figs. 5-9 Crustoderma dryinum: 5. Basidiocarp showing hymenial surface; 6. Basidiospores; 7. Basidia; 8. Cystidia and 9. Generative hyphae.

the base and extends towards the margins when fresh, somewhat darkening on drying; hymenial surface poroid, orange white to greyish orange when fresh, somewhat darker on drying; pores round to angular to daedaleoid, 2-3 per mm; dissepiments thin, entire; context homogenous, up to $5 \mathrm{~mm}$ thick, orange white; pore tubes up to $3 \mathrm{~mm}$ long, concolorous with hymenial surface; margins acute to obtuse, regular to somewhat wavy, sterile up to $1 \mathrm{~mm}$ on the hymenial surface, concolorous on both the sides. Hyphal system trimitic. Generative hyphae up to $4 \mu \mathrm{m}$ wide, branched, septate, clamped, thin-walled, subhyaline; skeletal hyphae up to 5.6 $\mu \mathrm{m}$ wide, unbranched, aseptate, thick-walled; binding hyphae up to $3.7 \mu \mathrm{m}$ wide, irregularly branched, aseptate, thickwalled. Cystidia absent, but cystidioles present in the hymenial layer, 20.6-26 $\times 4-5 \mu \mathrm{m}$, fusoid, thin-walled, with basal clamp. Basidia 20-25 $\times 6.8-8 \mu \mathrm{m}$, clavate, subhyaline, with basal clamp, 4-sterigmate; sterigmata up to $4 \mu \mathrm{m}$ long. Basidiospores 6.8-10 × 3-4.3 $\mu \mathrm{m}$, ellipsoid to subcylindrical, smooth, subhyaline, inamyloid, acyanophilous. 

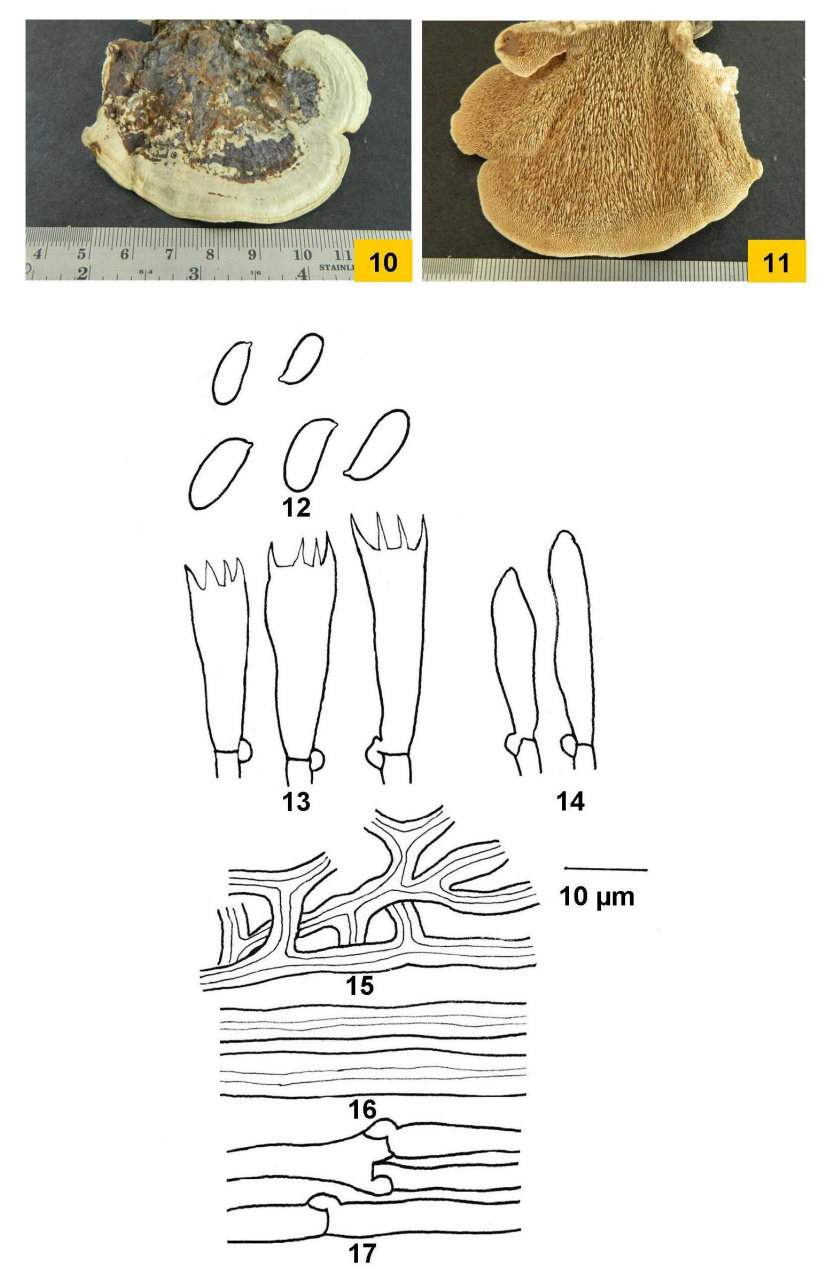

Figs. 10-17 Earliella scabrosa: 10 . Basidiocarp showing abhymenial surface; 11. Basidiocarp showing hymenial surface; 12. Basidiospores; 13. Basidia; 14. Cystidioles; 15. Binding hyphae; 16. Skeletal hyphae; 17. Generative hyphae.

Collection examined: Himachal Pradesh: Kullu, Banjar (Tandi), on angiospermous log, Ellu 9561 (PUN), 26.09. 2015.

Remarks: From India, E. scabrosa was first described by Berkeley (1854) as Trametes hookeri based on specimens collected from Darjeeling (West Bengal). Sharma (1997) and Leelavathy and Ganesh (2000) reported it as Trametes scabrosa from Sikkim and Kerala, respectively. However, Sharma (2000) listed it as Earliella scabrosa in the genera of Indian polypores. Kaur (2013) and Kaur et al. (2017a) also described it as Earliella scabrosa from districts Una, Bilaspur, Sirmaur and Kangra in Himachal Pradesh.

4. Ganoderma australe (Fr.) Pat., Bulletin de la Société Mycologique de France 5: 71, 1889.

Polyporus australis Fr., Elenchus Fungorum 1: 108, 1828.

Figs. 18-24

Basidiocarp perennial, pileate, sessile, solitary to imbricate; pilei up to $15 \times 12 \times 4 \mathrm{~cm}$, dimidiate to applanate, corky to woody; abhymenial surface non-laccate, smooth to
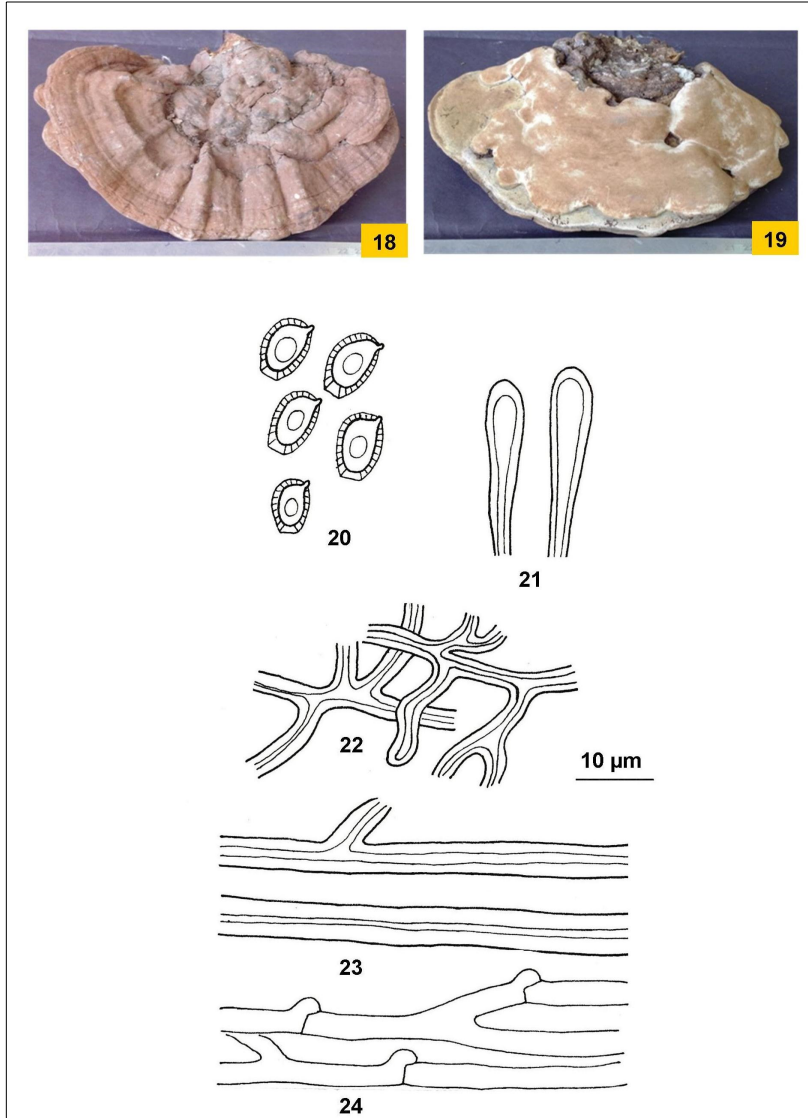

Figs. 18-24 Ganoderma australe: 18. Basidiocarp showing abhymenial surface; 19 . Basidiocarp showing hymenial surface; 20. Basidiospores; 21. Cuticular elements; 22. Binding hyphae; 23. Skeletal hyphae; 24. Generative hyphae.

rough to tuberculate, concentrically sulcate and weakly zonate, brown to dark brown when fresh, not changing much on drying, covered with spores; hymenial surface poroid, greyish yellow to brown when fresh, not changing much on drying; pores round, 3-4 per mm; dissepiments thin, entire; context homogenous, up to $3 \mathrm{~cm}$ thick, brown to dark brown; pore tubes up to $1 \mathrm{~cm}$ long, indistinctly stratified, brown, stuffed with white mycelium; margin thin, obtuse, regular, somewhat wavy, sterile, up to $1 \mathrm{~mm}$ on the hymenial surface, concolorous; pilear crust anamixodermis, very hard, not easily broken when depressed by nail, dark brown to blackish, shiny. Hyphal system trimitic. Generative hyphae up to $3.7 \mu \mathrm{m}$ wide, branched, septate, clamped, thin-walled, subhyaline; skeletobinding hyphae up to $5 \mu \mathrm{m}$ wide, arboriform, less branched near the stalk, more branched near the distal end, aseptate, thick-walled, brown; binding hyphae up to $3 \mu \mathrm{m}$ wide, irregularly branched, aseptate, thick-walled. Basidia not seen. Basidiospores 7.5-9.3 × 5-6 $\mu \mathrm{m}$, ellipsoid, truncate at the apex; exospore, thin, subhyaline, smooth; endospore, thick, echinulate, inamyloid, acyanophilous.

Collection examined: Himachal Pradesh: Kullu, Banjar, Manglore, on Prunus persica log, Ellu 9562(PUN), 17.08.2015. 
Remarks: $G$. australe was reported earlier from West Bengal, Kerala, district Kangra (Himachal Pradesh) and Union Territory of Chandigarh (Sharma and Ghosh, 1989; Leelavathy and Ganesh, 2000; Kaur, 2013; Kaur et al., 2017b).

5. Physisporinus lineatus (Pers.) F. Wu, Jia J. Chen \& Y.C. Dai, Mycologia 109 (5): 160, 2017.

Polyporus lineatus Pers., Botanique 5:174, 1827.

Figs. 25-31

Basidiocarp annual, effused-reflexed to pileate; pilei up to $6 \times 4 \times 0.6 \mathrm{~cm}$, dimidiate, imbricate, coriaceous when fresh, woody hard on drying; abhymenial surface smooth, with fine concentric zones, yellowish white to pale orange to greyish orange to greenish (because of algal growth) when fresh, not changing much on drying; hymenial surface poroid, pale orange to greyish orange when fresh,

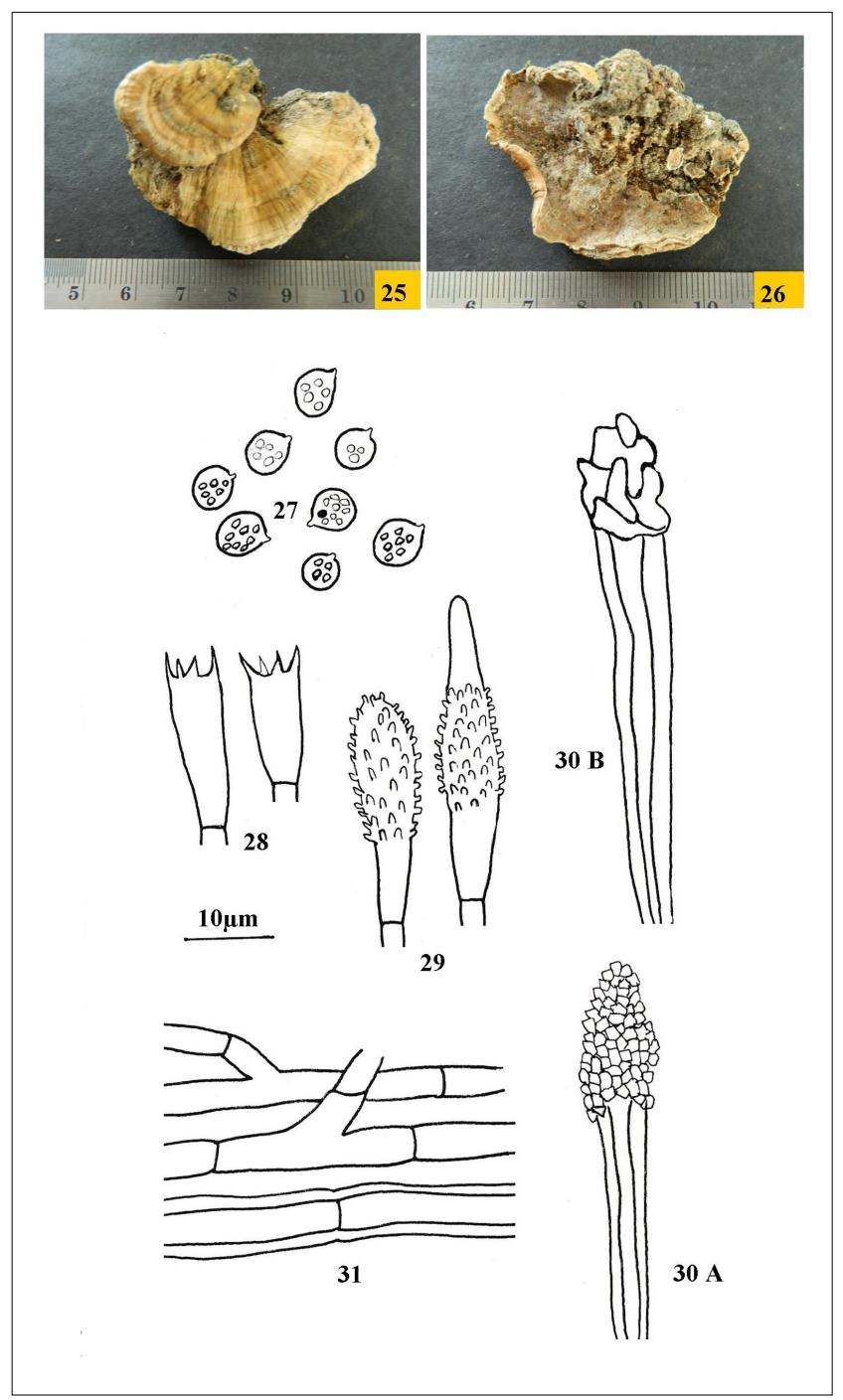

Figs. 25-31 Physisporinus lineatus: 25. Basidiocarp showing abhymenial surface; 26 . Basidiocarp showing hymenial surface; 27. Basidiospores; 28. Basidia; 29. Acanthocystidia; 30A Cystidium with encrustation; 30B. Cystidium with dissolved encrustation; 31 . Generative hyphae. not changing much on drying; pores round to angular, 6-9 per $\mathrm{mm}$; dissepiments thin, entire; context homogenous up to $4 \mathrm{~mm}$ thick, orange white to pale orange; pore tubes up to $2 \mathrm{~mm}$ long, orange white; margin thining, regular to wavy to lobed, incurved on drying, sterile up to $1 \mathrm{~mm}$, paler to concolorous. Hyphal system monomitic. Generative hyphae up to $6.8 \mu \mathrm{m}$ wide, branched, simpleseptate, thin- to thick-walled, subhyaline. Cystidia 40.6$56 \times 8-9 \mu \mathrm{m}$, cylindrical with somewhat swollen apical region, coarsely encrusted, thick-walled; generally embedded in trama to partly projecting into hymenium. Acanthocystidia 25-33 $\times 6-7 \mu \mathrm{m}$, generally present at the apex of dissepiments, hyaline, thin-walled, without basal clamp. Basidia 12-16.8 $\times 5-5.6 \mu \mathrm{m}$, clavate to subcylindrical, without basal clamp; 4-sterigmate; sterigmata up to $3 \mu \mathrm{m}$ long. Basidiospores 4.3-5.6 $\times$ 4.3-5 $\mu \mathrm{m}$ in diameter, globose to subglobose, smooth, subhyaline, with oily contents, inamyloid, acyanophilous.

Collection examined: Himachal Pradesh: Kullu, Banjar, Manglore on angiospermous wood, Ellu 9567 (PUN), 10.10. 2014.

Remarks: Physisporinus lineatus was first recorded from India as Polyporus zonalis by Hennings (1900), Bose (1920) and Banerjee (1947). However, Bakshi (1971), Dhanda (1977), Leelavathy and Ganesh (2000) and Kaur (2013) described it under genus Rigidoporus.

6. Pycnoporus sanguineus (L.) Murrill, Bulletin of the Torrey Botanical Club31 (8): 421, 1904.

Boletus sanguineus L., Species Plantarum: 1646, 1763.

Figs. 32-39

Basidiocarp annual, effused-reflexed to pileate; pilei up to $5.2 \times 4 \times 0.3 \mathrm{~cm}$, dimidiate, solitary to rarely imbricate; abhymenial surface smooth to tuberculate, azonate to faintly zonate, greyish orange to reddish orange when fresh, brownish red to reddish brown on drying; hymenial surface poroid, greyish red to brownish red when fresh, not changing much on drying; pores round to angular, 4-5 per $\mathrm{mm}$; dissepiments thick, entire; context homogenous, up to $2 \mathrm{~mm}$ thick, orange; pore tubes up to $1 \mathrm{~mm}$ long, light orange; margin acute to round, regular to wavy to somewhat lobed, sterile up to $2 \mathrm{~mm}$, light orange on both abhymenial and hymenial surface. Hyphal system trimitic. Generative hyphae up to $3.6 \mu \mathrm{m}$ wide, branched, septate, clamped, thinwalled, subhyaline; skeletal hyphae up to $6 \mu \mathrm{m}$ wide, rarely branched, aseptate, thick-walled, yellowish brown; binding hyphae up to $3 \mu \mathrm{m}$ wide, irregularly branched, thick-walled, yellowish brown. Cystidia absent, but cystidioles present in hymenial layer, 23-28 $\times 4-4.5 \mu \mathrm{m}$, fusoid, thin-walled, with basal clamp. Basidia 9-15 $\times 4-5 \mu \mathrm{m}$, clavate to subclavate, with basal clamp, subhyaline, 4-sterigmate; sterigmata up to $2 \mu \mathrm{m}$ long. Basidiospores 5-6 $\times 2.5-3 \mu \mathrm{m}$, ellipsoid to subcylindrical, smooth, subhyaline, inamyloid, acyanophilous.

Collection examined: Himachal Pradesh: Kullu, Banjar, Bahu, on angiospermous log, Ellu 9566 (PUN), 26. 09. 2015. 

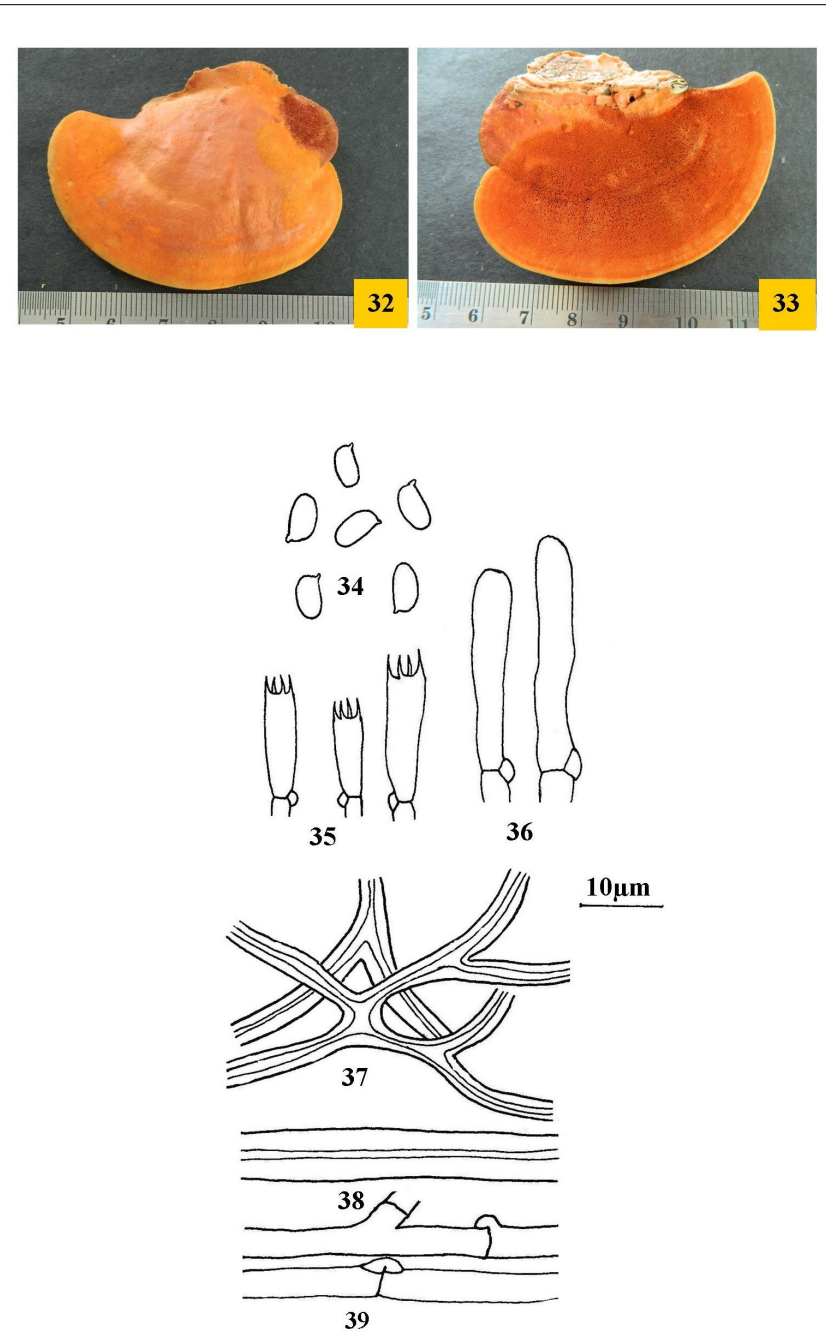

Figs. 32-39 Pycnoporus sanguineus: 32. Basidiocarp showing abhymenial surface; 33 . Basidiocarp showing hymenial surface; 34 Basidiospores; 35. Basidia; 36. Cystidioles; 37. binding hyphae; 38. Skeletal hyphae; 39. Generative hyphae.

Remarks: Earlier reports of this species are from Uttarakhand (Dhanda, 1977; Sharma, 2012) and Kerala (Leelavathy and Ganesh 2000).

7. Skvortzovia georgica (Parmasto) G. Gruhn \& Hallenb., Bulletin Mycologique et Botanique Dauphiné-Savoie 231: 6, 2018.

Phlebia georgica Parmasto, Eesti NSV Tead. Akad. Tom., Biol. seer 16:390, 1967.

Figs. 40-43

Basidiocarp resupinate, closely adnate, effused, $\leq 280 \mu \mathrm{m}$ in section; hymenial surface, mostly smooth, creamish white when fresh, yellowish white on drying; margins varying, indeterminate. Hyphal system monomitic. Generative hyphae branched, septate, clamped; basal hyphae up to $3 \mu \mathrm{m}$, straight, sparsely branched, septate, thin- to thick-walled; subhymenial hyphae up to $2.5 \mu \mathrm{m}$ wide, thin-walled, richly branched. Cystidia 35.6-43 × 5.6-6 $\mu \mathrm{m}$, subfusiform, obtuse, often
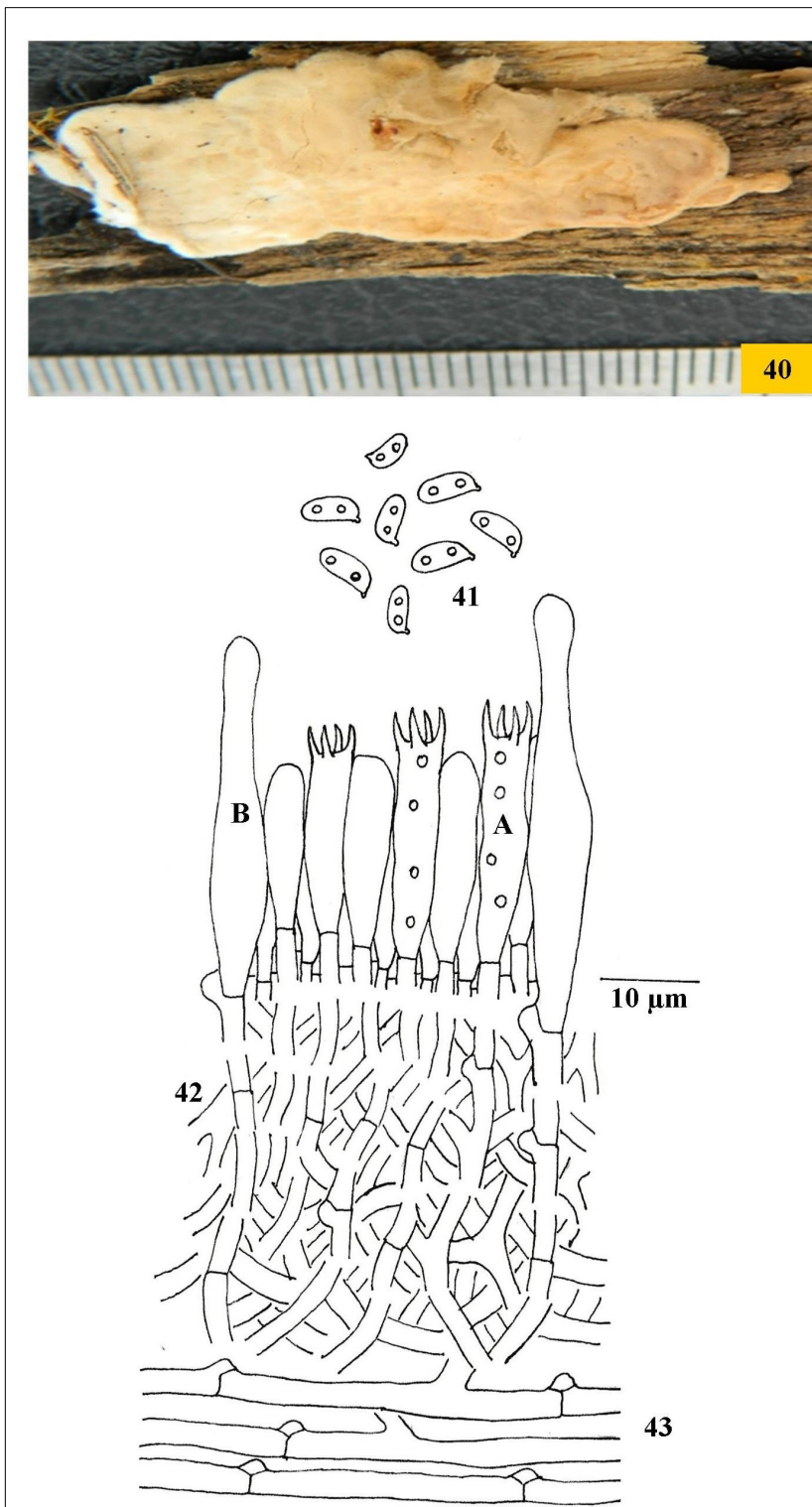

Figs. 40-43 Skvortzovia georgica: 40. Basidiocarp showing hymenial surface; 41 . Basidiospores; 42. Reconstruction of hymenium and subhymenium (A. Basidium; B. Cystidium); 43. Generative hyphae.

subcapitate, thin-walled, with basal clamp; projecting up to 8 $\mu \mathrm{m}$ out of hymenium. Basidia 17-22 $\times 5-5.3 \mu \mathrm{m}$, clavate to subcylindrical, with basal clamp, 4-sterigmate; sterigmata up to $3 \mu \mathrm{m}$ long. Basidiospores 5-6 $\times 1.8-2.5 \mu \mathrm{m}$, sub-allantoid, thinwalled, smooth, inamyloid, acyanophilous.

Collection examined: Himachal Pradesh: Kullu, Banjar, Gushaini, on Cedrus deodara log, Ellu 9565(PUN), 10. 10.2014.

Remarks: Skvortzovia georgica is unique in having somewhat smaller sub-allantoid basidiospores and is known from Russia, Swedon, Norway, USA(Mycobank, 2019). This is the first report of Skvortzovia georgica from India. 


\section{ACKNOWLEDGEMENTS}

The authors are grateful to the Head, Department of Botany, Punjabi University, Patiala for providing necessary laboratory facilities and University Grants Commission, New Delhi for financial assistance under UGC-SAP-DSA-I programme.

\section{REFERENCES}

Bakshi, B.K. 1971. Indian Polyporaceae (on trees and timber). Indian Council of Agricultural Research, New Delhi. 246 pp.

Banerjee, S.N. 1947. Fungus flora of Calcutta and Suburbs I. Bull. Bot. Soc. Bengal 1:37-54.

Berkeley, M.J. 1854. Decades XLVII, XLVIII. Indian Fungi. Hook. Journal of Botany 6: 204-212.

Bernicchia, A. and Gorjón, S.P. 2010. Corticiaceae s.1. Fungi Europaei 12. Edizioni Candusso. Alassio. Italia. $1008 \mathrm{pp}$.

Bose, S.R. 1920. Fungi of Bengal: Polyporaceae of BengalIII. Bull. Carmichael medical College 1: 1-5.

Brar, J.K., Kaur, R., Kaur, G., Singh, A.P. and Dhingra, G.S. 2018. Taxonomic notes on the genus Ganoderma from Union Territory of Chandigarh. Kavaka 51: $35-48$.

Dhanda, R.S. 1977. Studies on Polyporaceae of North Western Himalaya. Ph.D. Thesis. Panjab University, Chandigarh 500 pp.

Dhingra, G.S., Priyanka and Kaur, J. 2011. A checklist of resupinate, nonporoid Agaricomycetous fungi from NorthEast India and Bhutan. Synopsis Fungorum 29: $22-70$.

Dhingra, G.S., Singh, A.P., Kaur, J., Priyanka, Kaur, H., Rani, M., Sood, S., Singla, N., Kaur, H., Jain, N., Gupta, S., Kaur, M., Sharma, J., Rajnish and Kaur, G. 2014. A checklist of resupinate, nonporoid Agaricomycetous fungi from Himachal Pradesh, India. Synopsis Fungorum 32: 8-37.

Hennings, P. 1900. Fungi Indiae Orientalie I. Hedwigia 39: $150-153$.

Kaur, G. 2017. Taxonomic Studies on poroid and resupinate non-poroid Agaricomycetous fungi of Punjab and adjoining areas. Ph.D. Thesis. Punjabi University, Patiala. 341pp.

Kaur, H. 2013. Systematics of pileate poroid Agaricomycetes of Himachal Pradesh. Ph. D. thesis. Punjabi University, Patiala. 371pp.

Kaur, J. 2012. Studies on resupinate, nonporoid Agaricomycetous fungi from Himachal Pradesh. Ph.D. Thesis. Punjabi University, Patiala. 256 pp.

Kaur, R., Kaur, H., Singh, A.P., Kaur, G. and Dhingra, G.S. 2017a. Some noteworthy additions to family Polyporaceae from Himachal Pradesh. Kavaka 49:10-14.
Kaur, G., Singh, A.P. and Dhingra, G.S. 2017b. Diversity of the genus Ganoderma in Punjab (India) Mycobiota 7: $25-49$.

Kaur, M., Kaur, R., Singh, A.P., and Dhingra, G.S. 2018. Some noteworthy additions to family Phanerochaetaceae from district Shimla (Himachal Pradesh). Journal on New Biological Reports 7(1): 38-49.

Kornerup, A. and Wanscher, J.H. 1978. Metheun's Handbook of Colours, $3^{\text {rd }}$ Ed. Metheun and Co. Ltd. London. $252 \mathrm{pp}$.

Leelavathy, K.M. and Ganesh, P.N. 2000. Polypores of Kerala. Daya Publishing House, Delhi. 166 pp.

Mycobank, 2019. Fungal Databases. Nomenclature and species banks (Accessed: August 5, 2019).

Prasher, I.B. and Ashok, D. 2013. A checklist of wood rotting fungi (nongilled Agaricomycotina) of Himachal Pradesh. Journal on New Biological Reports. 2 (2): 71-98.

Priyanka, 2012. Studies on resupinate Polyporales (Agaricomycetes) of Himachal Pradesh. Ph.D. Thesis. Punjabi University, Patiala. 226 pp.

Ranadive, K.R. 2013. An overview of Aphyllophorales (wood rotting fungi) from India. Int. J. Curr. Microbiol. App. Sci. 2 (12): 112-139.

Rattan, S.S. 1977. The resupinate Aphyllophorales of the North Western Himalayas. Bibliotheca Mycologica 60, Cramer, Germany. 427 pp.

Ryvarden, L. and Melo, I. 2014. Poroid Fungi of Europe. Synopsis Fungorum. 455 pp.

Sanyal, S.K. 2014. Taxonomic studies on resupinate Polyporales of Uttarakhand. Ph. D. Thesis. Punjabi University, Patiala. 300 pp.

Sharma, J.R. 1997. Wood-rotting fungi (Aphyllophorales) from Sikkim. Bull. Bot. Surv. Ind. 34: 89-99.

Sharma, J.R. 2000. Genera of Indian Polypores. Botanical Survey of India, Ministry of Environment and Forests, Calcutta. 188 pp.

Sharma, J.R. 2012. Aphyllophorales of Himalaya. Botanical Survey of India, Ministry of Environment and Forests, Calcutta. 590 pp.

Sharma, J.R. and Ghosh, P.K. 1989. Polypores that decay tree of Indian Botanic Garden. Bull. Bot. Surv. Ind. 31: 95-102.

Singh, A.P. 2007. Resupinate Aphyllophoraceous fungi associated with some tree species of Himachal Pradesh and Punjab. Ph. D. Thesis. Punjabi University, Patiala. $258 \mathrm{pp}$.

Thind, K.S. and Dhingra, G.S. 1985. Thelephoroid fungi of the Eastern Himalaya I. Res. Bull. (Sci.) Panjab Univ. 36: 165-174. 